\author{
KOSTIANTYN RODYHIN, \\ Vasyl' Stus Donetsk National University (Vinnytsia, Ukraine) \\ e-mail: rodygin88@gmail.com,ORCID 0000-0002-2948-5393
}

MYKHAILO RODYHIN,

L.M. Litvinenko Institute of Physical-Organic Chemistry and Coal Chemistry,

The National Academy of Sciences of Ukraine (Kyiv, Ukraine)

e-mail: rodygin@ukr.net,ORCID 0000-0001-6826-7623

\title{
THE TRADITION OF ALCHEMICAL AND ASTROLOGICAL KNOWLEDGE WITHIN AND AROUND THEOPHAN PROKOPOVYCH'S LIBRARY
}

\begin{abstract}
The important role of the alchemical and astrological tradition in the formation and transformation of science as a social institution in the Early Modern period is researched in detail in Western historiography of science. At the same time, the Ukrainian aspect of this pan-European phenomenon needs further intensive study.

The article deals with the alchemical and astrological component of Ukrainian science of the High Baroque era on an example of Theophan Prokopovych (1677 - 1736). The analysis of the catalog of Prokopovych's library confirmed that the alchemical-astrological and magical-physical knowledge belonged to the sphere of interests of the scholar. His activity, in addition to cosmogonic reasoning and mathematical calculations, also had a practical component. Books from the library's holdings included works of late alchemy, which allowed Prokopovych to be aware of the latest ideas, trends, and achievements in this and related fields of knowledge. This is reflected in the formation of the worldview and creative work of the scholar.

A comparison of the facts of biographies, the essence and direction of creativity, and the relationship of the authors mentioned in Prokopovych's treatise "Natural Philosophy or Physics", testified to the existence of the united pan-European scientific and information space, within which the tradition of late alchemy was formed and transformed during the 16th-18th centuries. Theophan Prokopovych also belonged to this tradition, and his works reflected the state and essence of Ukrainian alchemical knowledge of the High Baroque era. Prokopovych's own views on problems of alchemy and astrology are a topic of special research.
\end{abstract}

Key words: alchemy, astrology, history of natural science, library, natural philosophy, Theophan Prokopovych, tradition, Ukrainian Baroque.national strategy of industrialization and modernization.

Introduction

In the history of natural science, due to the external similarity of manifestations, alchemy is traditionally considered as a chronological and sometimes essential predecessor of chemistry, astrology - of astronomy, magic - of physics (Kudriavtsev, 1951: 70-71), and the correspondding stages of formation and development of these disciplines ${ }^{1}$. Methodologically, to some extent, this seems appropriate, but one should notice that with the formation of the scientific paradigm and its subordinate disciplines, none of these components of the ancient complex of socalled "sorcerous knowledge" ${ }^{\text {"2 }}$ has disappeared from the

\footnotetext{
${ }^{1}$ The literature also presents an alternative point of view, which, despite its significance, does not contradict the idea of the existence of a complex of "sorcerous sciences". Thus, according to Nikolai Morozov, alchemy was the logical conclusion of magic and the next, second stage in the development of the science of matter and its transformation, initiated in ancient times within the magical tradition (Morozov, 1909: 31).

2 During the "Rosicrucian Enlightenment" of the 17th century (Yates, 1972), proto-scientific, alchemical, astrological, magical, Kabbalistic ideas did not exist in the usual for the Enlightenment opposition "science vs. magic", but in a unique complex. This knowledge, declared as "natural magic", despite self-attempts to
}

cultural and historical space. Thus, we are talking about related, but different socio-cultural phenomena that require separate study and understanding in the general civilizational dimension, considering the mental and national features of development.

Over the past two centuries, a huge amount of diverse and multi-vector scientific research was devoted to the study of these "sorcerous knowledge" phenomena in the Western socio-cultural space, their role in the formation and transformation of science as a social institution. However, this cannot be said about the state of research of the problem in Ukraine. E.g., it is declared that information about the pre-university period of astronomy in Ukraine is in a state of "information vacuum" (Petruk, 2014a: 6). Studies of the initial stage of chemistry deve-

distinguish it from "black magic", could somehow bear the imprint of the popular association with the image of "sorcery" of the Faustian type (see (Filonenko, 2017: 68-69)). In the sociocultural dimension, the term "complex of sorcerous knowledge" (Starostin, 1981: 13-14) seems to be quite accurate and capacious. Perhaps, the further radical separation of science from magic was originally a way of self-defense of scientists amid the "witch hunt". 
lopment are in a similar state. In the 21st century, there are few attempts to shed light on this issue (Semrad, Lendiel, Kokhan, 2003: 39-45), the main message of which is the statement that "the period in the history of chemistry from the 13th to the middle of the 18th century, in Ukraine and Russia, ... from... the decline of Kyivan Rus to M. Lomonosov, remains little studied" (Semrad, Lendiel, Kokhan, 2003: 41). The situation of nonacquaintance, non-recognition, and misunderstanding of Ukrainian achievements in this field is an objective consequence of the lack of factual material formed due to the 20th-century systematic destruction of book collections, removal of samples of material and spiritual culture, prohibition, and obstacles to research national features of scientific development (Petruk, 2014a: 6).

Actually, in Russia, the state of research of the early stages of development of natural science does not look better. In Soviet historiography, it was postulated that "Russian natural science began with Lomonosov" (Kudriavtsev, 1951: 277; Figurovskii, 1979: 44). Regarding the coverage of the state of early chemistry in Russia, the "History of Chemistry" by S. Orlovskii seems uninformative (Orlovskii, 1959: 22). The most thorough source on this topic today is N. Figurovskii's "Essay on the General History of Chemistry" (Figurovskii, 1969: 167-184), although there the coverage of the topic is sporadic and accentuated, e.g., the herbalism of Kyivan Rus and the development of chemical industries in Muscovy as well as in numerous annexed territories, are represented as achievements of Russian science. Also, there is a statement in the literature about the rejection of the "complex of sorcerous knowledge" of alchemy and astrology by old Rus's science as a "manifestation of a sober approach" (Starostin, 1981: 13-14).

Few studies in the history of chemistry with national accents have been performed in Soviet times. These include a fundamental study by T. Kazanjian, which contains extensive information on early chemistry and alchemy in Armenia (Kazanjian, 1955) and has made further progress (Chaloian, 1962). With some caution, it seems possible to add to the topic the achievements of U. Karimov's study of Razes's work (Karimov, 1957). However, even against this not very optimistic background, the early modern history of Ukrainian natural science looks like a "solid white spot" (ShevchenkoSavchynska, Balashov, 2014: 432). Because of this, there is an important task of clarifying the role and place of the Ukrainian component in the sum of ideas, beliefs, and sciences of those times, which requires meticulous analytical study of information sources (see: (Ruska, 1937)) and incorporating them into the general European context.

The study aims to identify and consider the components of the European alchemical and astrological tradition in early modern Ukrainian science on the materials of scientific and pedagogical activities of Theophan Prokopovych (other spellings: Theophanes Prokopowicz, Feofan Prokopovich, 1677-1736), a Ukrainian scientist and church figure of the High Baroque era; further coverage of his role in the history of Ukrainian science.

Research methodology

The basis of the research methodology is the historiographical method. In this way, information about the li- brary of Theophan Prokopovych and the context of his era in scientific and social development was analyzed. In the practice of the history of natural science, the method of personification has proved to be effective. Here, the essence and manifestations of a phenomenon are clarified through the study of the circumstances of life and the work of its representatives. Within the framework of this method, a search was made for the information on the personalities of alchemical authors appearing in Prokopovych's library or his works. Additionally, the method of studying the primary sources was used: on the materials of Prokopovych's treatise "Natural Philosophy or Physics" (1708 - 1709); works of other authors of the Ukrainian Baroque era, which constitute the general cultural context; works of alchemical and astrological tradition. A comparative method was used to compare them.

\section{Results and discussion}

Recently, a collection of new studies of astronomy in Ukraine in the 17th - 18th centuries was published $(P e-$ truk, 2014b), where Prokopovych's activities were given considerable attention (Koltachykhina, 2014: 197, 199; Matviishyn, 2014: 382, 400; Fedorovych, 2014: 177). The list of his property compiled after his death indicated the presence of astronomical tools - irrefutable evidence that the scientist's work was not limited to scholastic reflections and speculative considerations, but also had a practical component (Chyzhevskii, 2003: 472-474).

Rev. Theophan's involvement in astrological and astronomical activities is undeniable, and it required a certain professional qualification of the user, so in sociocultural coordinates, along with alchemy, it was attributed to the sphere of "high magic" (Dysa, 2014: 202). Often, natural actions of alchemical and astrological nature were thought of as elements of a single complex. E.g., Prokopovych shares a well-established opinion about the origin of mineral deposits: minerals, penetrating the nearest earth, make it suitable to transform into a similar kind under the influence of light, because minerals can be formed due to celestial bodies (Prokopovych, 1980: 482).

The Western integral perception of the sciences and the involvement of the clergy in this kind of activity were also characteristic of Ukraine, which left its mark, especially in the fine arts. Thus, in a panegyric in honor of the Orthodox Metropolitan of Kyiv Raphael Zaborovskyi (1739), his portrait was surrounded by personified figures embodying philosophy, medicine, poetry, and astronomy (Sydor, 2014: 281). Similar motifs are typical of Ukrainian Baroque literature. Glorifying the deeds of Prince VasylKostiantyn of Ostroh, Simon Pecalides (1600) also used similar allegories: Phoebus would crown the young people with a green laurel; he would show them the stars shining in the sky; he would also give them a cithara, teach them to heal and to know the future (Simon Pecalides, 2006: 298).

The astrological-alchemical connections inherent in the medieval worldview were realized on Ukrainian soil in full accordance with the European tradition. The art of medicine related to the alchemical activities was mentioned by Simon Pecalides in the same line with the astrological goal to "know the future", and this fact had a serious historical basis. By the 18th century, in Ukraine, Arabic astrological and astronomical works were available in Latin translations, which were very popular in Western Europe during the Middle Ages, in particular, were the 
subject of interest of such prominent philosophers and scholars of alchemy as Albert the Great, Roger Bacon, Pico Della Mirandola (Dysa, 2014: 526). Thus, the special literature of that time provided the transmission of ancient knowledge to Ukraine. History has preserved information that the complex of astrological and alchemical knowledge was realized not only at the level of mystical correspondences but also within a completely natural scientific discourse. For example, there were attempts to draw parallels between the color of comets (an element of the spectral characteristics of the body in the modern sense) and their nature - an analog of the modern idea of chemical composition (Shevchenko-Savchynska, Balashov, 2014: 429).

By the times of Prokopovych, in the Hetmanate, there was a widespread book entitled "Mysterious Book of Albert the Great about the forces of herbs, stones, and animals, celestial birds, fish, reptiles, and beasts, and so on" (Книга таінственная Альберта Велікаго о сілах трав, каменей и животных, небесних птицъ, рыбъ, гадовъ и зверей и протчего). It is clear from the title that the Renaissance magical tradition attributed this work to the famous theologian of the era of "Christian doctors", one of the "pillars of alchemy" (Maier, 1617: 1), Albert the Great (Albertus Magnus, Albert von Bolstedt, c. 11931280). It is noteworthy that the title of the treatise echoed the natural scientific works of historical Albert "De Mineralibus", "De Vegetabilis", "De Animalibus". Along with other information, "The Mysterious Book..." contains a separate astrological section "The Book of Albert the Great on astrology, astronomy, so that everything that is said in his books would be done perfectly" (Книга Альберта Великаго с острологіи, звездогадания, даби все что в его книгах говорено совершенно делалось) (Dysa, 2014: 205, 210).

The book includes a "Note of the famous European astronomer Tycho Brahe" (Записка славного европейскаго астронома Тихо Брага), attributed to the authoritative Danish astrologer and alchemist Tycho Brahe (1546-1601) (Dysa, 2014: 206). In his ancestral estate, he established a laboratory where he practiced astronomical and alchemical exercises. Then, Brahe set up an observatory in the tower of Uraniborg Castle, and in its basement an alchemical laboratory with 16 special furnaces (Belyi, 1982: 68) - equipment of paramount importance. In his treatise "Libellus de Alchimia", Albert the Great, for example, devoted considerable attention to various furnaces in chapters 4-8 (Albertus Magnus, 1958: 354-355). One of the fundamental works of the "father of chemical technology" (Steinfeld, 1959: 23), the famous alchemist Johann Rudolf Glauber (1604-1668) is called "New Philosophical Furnaces" (Soloviev, 1983: 268).

Tycho Brahe also distinguished himself in the field of iatrochemistry, at least the medicines he produced were in demand in Copenhagen, which led to conflicts with local doctors and pharmacists. Not a single research work is devoted to the consideration of his activity (Thoren, Christianson, 2006; Nummedal, 2007)), and some facts of the biography of the scientist seem to echo the alchemical myth. Thus, in the laboratory, the scientist was allegedly assisted by his sister Sophia and his son-in-law Eric Lange (Belyi, 1982: 129-130). For a connoisseur of alchemy, the figure of the sister-alchemist named Sophia (Wisdom) reminds of the Sister, a character in the iconic alchemical treatise "Mutus Liber", which may be traced back into antiquity to the semi-historical figure of the alchemist Mary the Jewess (3rd century BC), or another Mary, the sister of the biblical Moses, who was also regarded as an alchemist (Rodichenkov, 2019: 96-98).

In his lectures, Theophan Prokopovych presented the cosmogonic ideas of this extraordinary scholar on a par with the systems of Ptolemy and Copernicus (Koltachykhina, 2014: 199). Thus, having a thorough knowledge of the astronomical component of Tycho Brahe's heritage, Prokopovych could be acquainted with its alchemical segment as well.

Courses of philosophy, where it is most likely to expect manifestations of alchemical worldview, were taught in the 17th-18th-centuries Kyiv-Mohyla Academy in a similar way as in European universities. This is quite explainable because that is where Ukrainian scientists were educated (Mykytas, 1994). According to preliminary data, only Galileo's lectures at the University of Padua between 1592 and 1610 were attended by 52 Ukrainian students. Many Ukrainians studied in Rome: Joasaph Krokovskyi, Theophylact Lopatynskyi, Innokentii Gizel, and others. Among them was Theophan Prokopovych (Koltachykhina, 2014: 197).

While studying in Rome (1698-1701), he became acquainted with the works of many famous mathematicians and astronomers and became interested in physical research. Most probably, his acquaintance with alchemical teachings took place then. Prokopovych's involvement in the alchemical tradition at the Russian imperial period of his activity is a proven fact (Collis, 2012: 52-77). However, there is a reason to believe that interest in alchemy arose much earlier and remained unchanged throughout the life of the scholar. This assumption is supported by a thematic analysis of his library, which was carefully assembled by him for many years. The history of Prokopovych's library, like that of the libraries of Yaroslav the Wise or Ivan IV the Terrible, acquired features of a semilegendary plot of "the lost ancient knowledge". After the owner's death, the library remained in the Novgorod seminary. In 1926, it was moved to the Library of the Academy of Sciences in Leningrad, and then, due to noncompliance with storage conditions, distribution of funds in various structures, and finally, the fire of 1947, the collection lost its integrity. Its current state is uncertain.

The catalog of the library, compiled by the professor of church history $P$. Verkhovskii, based on a manuscript from the Holy Synod archives (Verkhovskii, 1916: 9-36), has numerous flaws (Chyzhevskyi, 2003: 469-478), however, it allows us to form a general impression of Prokopovych's interests. Researchers note the presence of the typical Baroque "emblematic literature" (Chyzhevskyi, 2003: 469-478) and a significant number of books of natural scientific direction, which shows the desire of their owner to go to the essence of things, his unshakable faith in science and the human mind (Rohovych, 1981: 375).

The symbolism of thinking, natural scientific interest, epistemological optimism, and the desire to go beyond the routine of everyday life into the realm of the infinite are the hallmarks of the phenomenon of Western European alchemy (Rodygin, 2013). This applies not only to the unlimited material resource - alchemical gold but also to the source of universal health - Panacea and the almighty bearer of eternity - the Elixir of Immortality. This looked quite natural because, according to Prokopovych, all creatures were endowed by God with a certain desire 
or even thirst for their self-preservation and immortality (Prokopovych, 1980: 267).

From this selection of literature, Theophan Prokopovych was interested in the latest advances in science and methodology of cognition. Evidence of this is the work of the founder of the philosophy of empiricism Francis Bacon of Verulam (1561-1626) (Novum organum scientiarum, Amstelodami, apud 1. Ravens Steinium, $1660 \mathrm{ma}$ Opuscula doctissima. Bremae, apud Willerianum, MDCXIX) (Rohovych, 1981: 390), and outstanding, perhaps the most progressive naturalist of his time, the "skeptical chemist" Robert Boyle (1627-1691) (Experimenta et considerationes de coloribus. Genevae, apud S, de Tourmes, MDCLXXVI, No. 1565. Opera variia. Coloniae Allobrogum, apud $S$. de Tournes, MDCLXXVII, No. 1566. Specimen de gemmarum origine et institutionibus. Hamburgi, apud Gotofredum et Amstelodami, apud Janssonium, MDCLXXIII, No. 1768. (Collis, 2012: 546)).

Prokopovych referred to the authority of Robert Boyle in such a context that not only the acquaintance with the achievements of the outstanding Englishman but also the scholar's competence in matters of experimental science is beyond doubt.

Prokopovych wrote that it was not easy to study and investigate experimentally, how much heavier than air is water: Boyle, however, claimed that it was almost a thousand times heavier than air, while Borelli $i^{3}$ noted that specific weights of water and air are in ratio 1175:1. If this measurement was correct, wrote Rev. Theophan, it was easy to determine the weight of other bodies, comparing them with the weight of air (Prokopovych, 1980: 266-267).

Next to the names of modern scholars is the name of the humanist Erasmus of Rotterdam (1466 (1469?)1536) (Rohovych, 1981: 375), who, although in a satirical perspective, but did not ignore alchemy. One of his dialogues is called "The Alchemist" (Erasmus of Rotterdam, 1993: 195-202). Erasmus, along with other philosophers, was mentioned by Theophan Prokopovych dozens of times in his treatise "On Rhetorical Art" (Prokopovych, 1979: 123, 138-140, 159, 176, 315).

In general, when cataloging the library by prof. Verkhovskii, more than a hundred books were attributed to the rubric of alchemy and esotericism, including both littleknown works and books by prominent figures of alchemy - Olaus Borrichius (Ole Borch, 1626-1690) (Hermetis, Aegyptiorum et Chemicorum Sapeintia ab hermanni Conringii (Heidelberg, 1674, No. 1553), Giambattista Della Porta (1535 - 1615) (Portae Neapolitani Magiae Naturalis, No. 1144) and Otto Tachenius (Tacken, 1610 (1620?)-1680 (1690?)) (Hippocrates Chymicus, No. 1814) (Collis, 2012: 546-547).

The Westphalian naturalist and pharmacist Otto Tachenius was considered in the history of chemistry as a representative of the transitional stage between alchemy and scientific chemistry (Rodichenkov, 2019: 288-289). $\mathrm{He}$ abandoned the triad of Paracelsus (this outstanding reformer of alchemy (1493-1541) was mentioned in Prokopovych's "Natural Philosophy" as Aureol (Prokopovych,

\footnotetext{
${ }^{3}$ The Italian naturalist Giovanni Alfonso Borelli (1608-1679) was mentioned three times in the pages of "Natural Philosophy" and was characterized by Prokopovych as a very experienced experimenter (Prokopovych, 1980: 264-266). These passages concerned the barometric studies, however, discussing the properties of mercury and trying to explain them naturally brought these considerations closer to alchemical ones.
}

1980: 207)), but instead proposed recognizing two other alchemical universal principles of world construction (Soloviev, 1983: 264-265). Many of the authors mentioned by researchers in the context of this work need additional attention, such as Athanasius Kircher, Jacob Bernoulli, Girolamo Cardano, Galileo Galilei, Johann Kepler, "physician and chemist" Herman Boerhaave, Daniel Sennert (Rohovych, 1981: 375).

In his treatise "Natural Philosophy or Physics", Theophan Prokopovych mentioned that "the modern mathematician Athanasius Kircher" described in his work the great art of natural magic (Prokopovych, 1980: 154). A Jesuit intellectual Athanasius Kircher (1602-1680) was a mathematician, magician, alchemist, and one of the first researchers of the phenomenon of alchemy. Prokopovych's library contained his works (Ars Magna Lucis et Umbrae No. 1458. Ars Magnetica No. 1459. Eiuzdem Musurgia Universalis No. 1460) (Collis, 2012: 548). Mentions of this Jesuit scholar in "Natural Philosophy" (Prokopovych, 1980: 294, 315-316, 343-344, 346) were not uncommon, as his activities were directly within the scope of professional interests of Prokopovych. At least in 1641, Kircher published a treatise "Magnet, or About magnetic art in three books" (Rodichenkov, 2019: 309), and Rev. Theophan also paid considerable attention to this topic (Prokopovych, 1980: 498-500). At least, the cosmogonic ideas of Kircher were discussed and severely criticized by Prokopovych (Prokopovych, 1980: 315-316). Like Olaus Borrichius, Athanasius Kircher drew the roots of alchemy from the blacksmithing of the biblical Tubalcain, which seems important, because it established a deep relation between these areas three centuries before the studies of Dr. Mircea Eliade (Rodichenkov, 2013: 67).

Jacob Bernoulli (1655-1705) was a world-famous mathematician, a representative of the glorious dynasty of Swiss scientists. He studied astronomy and theology at the University of Basel. He came from a family of a successful pharmacist from Basel, which at that time almost certainly meant involvement in Paracelsianism, and hence in alchemical issues. Bernoulli was interested in the works of Robert Boyle and Robert Hooke (16351702), which tended toward alchemy (Ihde, 1964); corresponded with Gottfried Wilhelm Leibniz (1646-1716), who was not only famous as a mathematician and philosopher but also played an important role in the adventurous history of the discovery of elemental phosphorus by alchemist Hennig Brand (Dmitriev, 1984: 224-225). Jacob's younger brother, Johann Bernoulli (1667-1748) was engaged in pneumochemical research (Marcard, 1938: 183)

Gerolamo (Girolamo, Geronimo) Cardano (15011576) was a philosopher, mathematician, astrologer, astronomer, physician, a supporter of Kabbalah (Rodichenkov, 2019: 256), alchemist, author of the alchemical treatise "De immortalitate animorum". According to the catalog of prof. Verkhovskii, Prokopovych's library included Cardano's treatise "De Rerum Varietate", No.1661 (Collis, 2012: 548). Cardano was mentioned in "Natural Philosophy" at least twice, both times alongside significant authorities in natural science - the medieval Avicenna (Prokopovych, 1980: 477) and the ancient Anaxagoras (Prokopovych, 1980: 499). The latter mention seems not only an interesting curiosity in the history of physics but also an indicator of Prokopovych's assessment of Cardano's scientific reputation. According to the text, Anaxagoras 
taught about the living nature of a magnet as a cause of its attraction; among the modern authors, the famous philosopher Cardano joined him, and Agella the Jew agreed with this as well (Prokopovych, 1980: 499).

Daniel Sennert, one of the most-cited authors in "Natural Philosophy" (Prokopovych, 1980: 137-141, 232-235, 239-240, 243, 285, 329, 351, 380, 383, 388-391, 395, $398-399,405,419-420,445-446,455,461-462,482,485-$ $486,495-499,501)$, also joined the discussion on the nature of the magnet (Prokopovych, 1980: 499). This topic did not leave indifferent Julius Scaliger (14841558), the author mentioned by Prokopovych along with Sennert, however, the frequency of his mentions was slightly inferior to the latter (Prokopovych, 1980: 137, 139141, 383, 462, 498-500). Rev. Theophan noted that Scaliger explained magnetic properties with a coherence of nature, and he was right because no one could doubt that nature was coherent when one thing was attracted to another. But by what means it was attracted? - that was the question (Prokopovych, 1980: 499-500). Thus, Scaliger's thoughts were unlike the fantastic ideas of Anaxagoras or even the natural philosophical considerations of Cardano, because they bore the marks of Bacon's empiricism.

Theophan Prokopovych emphasized the importance of this approach for the methodology of natural science to the readers (listeners). He recommended them to read Sennert's works where the author emphasized the necessity of being guided more by experience than by the evidence of the theory itself, and that one following a theory without experience was more deeply mistaken than one following an experience without a theory. After all, in physics, science itself could not discover something obvious but took everything from experience. Therefore, the author wrote: for the theory not to limp, it must lean on another leg, namely, experience (Prokopovych, 1980: 420). Prokopovych testified that Sennert was well-versed in the question and participated in an important scientific disputation on the methodological and epistemological significance of the experience (Prokopovych, 1980: 389).

Daniel Sennert (1572-1637) was a philosopher, physician, physicist, and alchemist. Prokopovych mentioned him as a professor at the Wittenberg Academy of Medical Sciences (Prokopovych, 1980: 137-138), but at the same time, he did not seem to consider Sennert an undoubted authority calling him "vaunted" (Prokopovych, 1980: 141). At the beginning of his career as a scientist and practitioner, Sennert did not share alchemical ideas, but for some reason changed his mind. As can be seen from collection of his works, Opera Omnia, Sennert considered the two goals of chemistry/alchemy: first, a transmutation of metals, and second, a preparation of useful and effective medicines. He tried to combine the ideas of ancient atomism with modern-day ones, the teachings of Paracelsus with the views of Galenus, i.e., at the same time had a theoretical basis of natural philosophy, medicine, and Paracelsianism, and was well-informed about the problems and achievements of iatrochemistry (Rodichenkov, 2019: 264-265, 308). His writings also contained purely magical ideas, which were shared by Theophan Prokopovych stating that red jasper could stop nosebleeds and hemorrhoids. Then, Prokopovych referred to Sennert saying that probably both hemorrhages and internal bleedings which could not be stopped by any means, were stopped by a piece of jasper tied to one's hip (Prokopovych, 1980: 501). Here, Sennert's reasoning was like that of Scaliger, as it continued the medieval fantasy tradition of bestiaries and lapidaries ${ }^{4}$.

Along with Sennert, Prokopovych mentioned Alessandro Piccolomini (Prokopovych, 1980: 232) and Jean Bauhin (Prokopovych, 1980: 497). Piccolomini (1508-1578) worked in a wide range of sciences, including science, philosophy, theology. He was the author of the treatise "Book of Science of Nature", which can be considered evidence of his involvement in the hermetic tradition. Jean Bauhin (1511-1582) was a French naturalist and court pharmacist of the Queen of Navarro, i.e., a person whose official status presupposed knowledge of the alchemical field. His son, Johann, or Jean (1541-1613) became a Swiss botanist and a physician to Duke Friedrich I of Wuerttemberg.

There were many books by Daniel Sennert in Prokopovych's library: Compendium Institutionum Medicinae, Nos. 1502, 1641, Practicae Medicinae de liber tertius, No. 1569, Uratislaviensis Epitome Naturalis Sciencia, Nos. 1638, 1639, 1640, 1642 (Collis, 2012: 549). Rev. Theophan considered this author a significant figure (unusual, as for the Orthodox hierarch, assessment of activities of a Calvinist; apparently, this might to some extent explain the fact that after fleeing from Rome, Prokopovych returned home via Protestant countries, avoiding Catholic ones) and mention him along with other prominent figures of natural philosophy: Aristotle, Plato, Pythagoras, Plinius, Boethius, Albert the Great, etc. The scholar's attitude to one of the basic alchemical ideas, an idea of the spirituality of the world, seems interesting. Prokopovych wrote that Hermes Trismegistus, Zoroaster, and Orpheus considered the world alive, and Sennert shared their opinion, stating that everything was filled with souls. The same opinion was shared by Pythagoras, Plato, and their followers, who called the world a living being, attributing to it a soul that had a life-giving seed everywhere, on earth and in water (Prokopovych, 1980: 285).

The "universal seed" mentioned by Rev. Theophan seems alike the ubiquitous harmonizing factor of the Universe - the Aristotelian world ether or Quinta essentia or philosopher's stone of alchemists, and this was supported by the reference to the legendary founder of alchemical art, Hermes Trismegistus. Similar thoughts were found in the alchemical works of Basil Valentine: a tincture was thought of as the root of metals, a supernatural, volatile, fiery spirit contained in the air, earth, and water. This spirit was alleged to be found in all metals, and in Gold in abundance, because gold was considered a mature and perfect body (Basil Valentine, 2008: 175). Prokopovych

\footnotetext{
${ }^{4}$ Prokopovych told the following ideas, although it is difficult to say unequivocally to what extent he shared these considerations. One of these statements was about many stones being born in animals (Compare: "The Book of the Secret of the Secrets" by Razes contained a chapter named "On the Elixir consisting of four animal stones" (Karimov, 1957: 111-112) - K.R., M.R.). The most valuable of them was a stone called a deer's tear. Referring to Scaliger, Prokopovych stated that a deer did not use to have it until the hundredth year; after this age, that stone used to germinate on an eyelid and grow into a frontal bone of the deer's skull. This stone was told to be a valuable remedy against the poison; also, it had been prescribed to patients with plague with a drop of wine (Prokopovych, 1980: 498). Moreover, referring to Sennert, Prokopovych wrote about amber detecting epileptics and having the power to soften and disperse kidney stones, etc. (Prokopovych, 1980: 487).
} 
presented the idea of the "universal seed" as follows: most imperfect beings were born without parents under the influence of heaven; so, heaven had some productive ability to generate certain living creatures and minerals with their special forms (Prokopovych, 1980: 483).

Herman Boerhaave (1668-1738), a "physician and chemist" (Rohovych, 1981: 375), also derived the history of chemistry from Hermes. He was a student of Georg Stahl, one of the founders of the phlogiston theory, which determined the main path of development of chemical thought at that time. Boerhaave was rightly considered one of the first rational chemists, and Prokopovych had both volumes of his key work "Elementa Chemiae" (vol. 1, 1724, No. 1487., vol. 2, 1724, No. 1516) (Collis, 2012. 546). At the same time, he worked hard and persistently in the field of practical alchemy and did not deny the possibility of transmutation (Toor, 2011: 75-83). In the context of this study, the use of the traditional definition of "physician and chemist" (Medicus \& Chymicus) seems to be indicative. Namely, with this definition, the alchemist Hieronymus Reusner (Index librorum, 1747: 538), the author of "Lexicon alchemiae" Martin Ruland (Index librorum, 1747: 825), and the famous magician and hermeticist Cornelius Agrippa of Nettesheim (1486-1535) (Index librorum, 1747: 520) were inscribed in the Index of Forbidden Books. The works of the latter were found in Prokopovych's library (De Incertitudine et vanitate omnium scientiarum et atrium liber (Frankfurt and Leipzig, 1693), Nos. 1401-1402; Operum Pars Posterior, No. 1659) (Collis, 2012: 546, 548).

It was not surprising that the experienced naturalist Theophan Prokopovych was aware of the creative heritage of Johann Kepler (1571-1630) and Galileo Galilei (1564-1642). He paid considerable attention to the achievements of the latter (Prokopovych, 1980: 342-346, 380 , 382), calling him "a famous philosopher and mathematician" who discovered new planets using an optical tube (Prokopovych, 1980: 342). These ideas were revolutionary not only for Galileo in the 17th century, but also for Prokopovych in the 18th, as they undermined established views on the fundamental order of the Universe - the mystical correspondence of metals, days of the week, and planets.

For some time, Johann Kepler held the position of court astrologer to Emperor Rudolf II in Prague, the capital of European alchemy, so he could be involved in this case. A chemical analysis of the scientist's documents, conducted in 2019, revealed an increased content of heavy metals, which suggested that he practiced alchemical exercises, which he could learn from Tycho Brahe around 1600 (Flood, 2019). These circumstances allow us to extrapolate their consideration to the coordinates of the Polish-Lithuanian Commonwealth (Rzecz Pospolita Obojga Narodow), and therefore to consider it significant in the context of the phenomenon of alchemy in Ukraine. In the 1580s, the Polish politician and military figure OIbracht Laski (1536-1605) visited several European courts, including that of Emperor Rudolf II, i.e., was involved in alchemical circles, as well as the abovementioned Brahe and Kepler. Laski's attraction to the

\footnotetext{
${ }^{5}$ In Maciej Stryjkowski's "Chronicles of Poland, Lithuania, Samogitia and all of Ruthenia" (Krolevets, 1582), especially in the chapter "On ancient ceremonies, or rather madness..." we can find another modification of this definition: "one doctor, physician, and physicist" (Stryjkowski, 2006: 181).
}

sciences, including the "sorcerous" ones, was indirectly confirmed by the fact that in 1583 in Oxford, he participated in a debate with the famous philosopher and magician Giordano Bruno (Yates, 1972). Laski soon secretly left the court of Queen Elizabeth I, taking with him to Poland the famous alchemist and mathematician John Dee (1527-1608) (Matviishyn, 2014: 372). So, this provided the transmission of alchemical and astrological knowledge to the Commonwealth and their further spread in the Ukrainian land (Rodygin, Rodygin, 2012).

Even a cursory examination of biographical data, creative activity, and relationships of many European natural scientists appearing in this work ${ }^{6}$ in some way allow us to state firstly, their involvement in the complex of "sorcerous knowledge" and in particular, alchemy; secondly, the existence of a single pan-European scientific and information space by the 16th-18th centuries, that provided communication between scholars, dissemination of knowledge, and its further development.

\section{Conclusions}

The important role of the alchemical and astrological tradition in the formation and transformation of science as a social institution in the early modern era is covered in detail in Western historiography of science. The Ukrainian aspect of this pan-European phenomenon needs in-depth study. Based on this, the figure of Theophan Prokopovych as a polymath and one of the brightest intellectuals of the Ukrainian Baroque was chosen for consideration.

The catalog of Theophan Prokopovych's library testifies to the presence of a significant number of works of natural philosophical direction, including those belonging to non-university knowledge - alchemical-astrological and magical-physical complex or the so-called "sorcerous sciences". This is evidence of the interests of the library owner.

Prokopovych's astrological and astronomical interests are well-known, but the presence of special equipment among his personal property allows us to suggest the scientist's activity to have a practical component in addition to cosmogonic considerations and mathematical calculations.

In his writings, including the treatise "Natural Philosophy or Physics", he mentions and cites dozens of authors whose work had at least a distinct alchemical component. Alchemically oriented works were not only in the collection of Prokopovych but were the subject of persistent study, which was reflected in the worldview and creative work of the scholar, in particular, in his citations.

Books from the library's holdings belong to the works of late alchemy, which allowed Rev. Theophan to be aware of the latest ideas, trends, and achievements in this field and related fields of knowledge. The scholar's worldview includes well-established natural philosophical ideas of ancient philosophers and "pillars of alchemy" (including Avicenna and Albert the Great), iatrochemical views of the Paracelsians, the latest manifestations of

\footnotetext{
${ }^{6}$ Theophan Prokopovych, Agrippa of Nettesheim, Francis Bacon, Jean Bauhin, Jacob and Johann Bernoulli, Herman Boerhaave, Giovanni Borelli, Robert Boyle, Olaus Borrichius, Tycho Brahe, Giordano Bruno, Girolamo Cardano, John Dee, Erasmus of Rotterdam, Galileo Galilei, Robert Hooke, Johann Kepler, Athanasius Kircher, Gottfried Leibniz, Paracelsus, Alessandro Piccolomini, Julius Scaliger, Daniel Sennert, Georg Stahl, Otto Tachenius.
} 
Francis Bacon's empiricism, Robert Boyle's natural skepticism, the ideas of Becher-Stahl phlogiston theory.

The comparison of biographical data, analysis of the writings, and relationships of figures mentioned or cited in the works of Prokopovych allow us to suggest the existence of a single pan-European scientific and information space by the 16th-198th centuries that provided communication between scientists, dissemination of knowledge and its further development. In this way, the European late alchemical tradition was formed and transformed, and Theophan Prokopovych belonged to this tradition according to his beliefs and direction of thought. The treatise "Natural Philosophy or Physics" clearly reflects the state and essence of the alchemical component of Ukrainian scholarship of the High Baroque era.

Prokopovych's considerations on the problems of alchemy and astrology are the subject of further special research.

\section{REFERENCES}

Albertus Magnus (1958). Libellus de Alchimia. Translation by Sister Virginia Heines. Cambridge: Cambridge Univ. Press. $79 \mathrm{p}$.

Basil Valentine (2008). O estestvennykh i sverkhestestvennykh veshchakh, a takzhe o pervoj tinkture - korne i dukhe metallov i mineralov. In: Basil Valentine. Alkhimicheskie traktaty. Kyiv: Avtograf. P. 168-201 (in Russian)

Belyi, Yu.A. (1982). Tikho Brage. Moscow: Nauka. 229 p. (in Russian)

Chaloian, V.K. (1962). Predstavleniia o prirode $v$ trudakh loanna Erzynkatsi Pluza. Voprosy istorii estestvoznaniia $i$ tekhniki, 13: 112-114. (in Russian)

Chyzhevskyi, D. (2003). Ukrainske literaturne barokko. Kyiv: Oberehy. 576 p. (in Ukrainian)

Collis, R. (2012). The Petrine Instauration. Religion, Esotericism and Science at the Court of Peter the Great, 1689-1725. Leiden - Boston. 583 p.

Dmitriev, I.S. (1984). Kommentarii. In: Hoffman, C. Mozhno li sdelat zoloto? Leningrad: Khimiia. P.224-225. (in Russian)

Dysa, K. (2014). Astrolohiia v hospodarskykh poradnykakh Hetmanshchyny XVIII st. In: Petruk, O. (ed.) Ukrainske nebo. Studii nad istoriieiu astronomii $v$ Ukraini. Lviv: Pidstryhach Institute for Applied Problems of Mechanics and Mathematics, National Academy of Sciences of Ukraine. P.202-210. (in Ukrainian)

Erasmus of Rotterdam (1993). Alkhimik. In: Erasmus of Rotterdam. Pokhvala Hlupoti. Domashni besidy. Kyiv: Osnovy. P.195-202. (in Ukrainian)

Fedorovych, N. (2014). Astronomichni yavyshcha v ukrainskykh litopysakh i v davnii ukrainskii literaturi. In.: Petruk, O. (ed.) Ukrainske nebo. Studii nad istoriieiu astronomii $v$ Ukraini. Lviv: Pidstryhach Institute for Applied Problems of Mechanics and Mathematics, National Academy of Sciences of Ukraine. P. 156-185. (in Ukrainian)

Figurovskii, N.A. (1969). Ocherk obshchei istorii khimii. Ot drevneishikh vremen do nachala XIX v. Moscow: Nauka. 455 p. (in Russian)

Figurovskii, N.A. (1979). Istoriia khimii. Moscow: Prosveshchenie. 311 p. (in Russian)

Filonenko, O.H. (2017). Renesansno-barokovyi «mahichnyi kod» u brytanskii literaturi (na materiali tvoriv kintsia XVI - XX stolit). The thesis for a Candidate Degree in Philology. Mykolaiv: Petro Mohyla Black Sea National University. 250 p. (in Ukrainian)

Flood, A. (2019). Groundbreaking astronomer Kepler 'may have practised alchemy'. The Guardian. June 13. URL https://www.theguardian.com/books/2019/jun/13/groundbrea king-astronomer-kepler-may-have-practised-alchemy (accessed on November 30, 2021)
Ihde, A.J. (1964). Alchemy in reverse: Robert Boyle on the degradation of Gold. Chymia. Philadelphia: Pennsylvania Univ. Press. 9: 47-57.

Index librorum prohibitorum, ac expurgandorum novissimus. Pro universis Hispaniarum regnis serenissimi Ferdinandi VI, Regis catholici (1747). Matriti. T.Il. 1193 p. (in Latin)

Karimov, U.I. (1957). Neizvestnoe sochinenie Ar-Razi «Kniga tainy tain». Tashkent: Izdatelstvo AN Uzb. SSR. 192 p. (in Russian)

Kazanjian, T.T. (1955). Ocherki po istorii khimii v Armenii. Erevan: Izdatelstvo Erevanskogo universiteta. 237 p. (in Russian)

Koltachykhina, O. (2014). Uiavlennia pro svitobudovu v Ukraini do XVII st. In: Petruk, O. (ed.) Ukrainske nebo. Studii nad istoriieiu astronomii $v$ Ukraini. Lviv: Pidstryhach Institute for Applied Problems of Mechanics and Mathematics, National Academy of Sciences of Ukraine. P. 186-201. (in Ukrainian)

Kudriavtsev, P.S. (1951). Istoriia fizyky. Kyiv: Radianska shkola. T. 1. 512 p. (in Ukrainian)

Maier, M. (1617). Symbola aurea mensae duodecim nationum. Francofurti. 662 p. (in Latin)

Marcard, R. (1938). Petite histoire de la chimie et l'alchimie d'Hermes a Lavoisier. Bordeaux: Ed. Delmas. 238 p. (in French)

Matviishyn, Ya. (2014). Idei Kopernyka v Ukraini. In: Petruk, O. (ed.) Ukrainske nebo. Studii nad istoriieiu astronomii v Ukraini. Lviv: Pidstryhach Institute for Applied Problems of Mechanics and Mathematics, National Academy of Sciences of Ukraine. P. 370-421. (in Ukrainian)

Morozov, N.A. (1909). V poiskakh filosofskago kamnia. SaintPetersburg. 303 p. (in Russian)

Mykytas, V. (1994). Davnioukrainski studenty i profesory. Kyiv: Abrys. 288 p. (in Ukrainian)

Nummedal, T. (2007). Alchemy and authority in the Holy Roman Empire. Chicago, III.; London: Univ. of Chicago press. 280 p.

Orlovskyi, S.T. (1959). Istoriia khimii. Kyiv: Radianska shkola. 415 p. (in Ukrainian)

Petruk, O. (2014a). Peredmova. In: Petruk, O. (ed.) Ukrainske nebo. Studii nad istoriieiu astronomii v Ukraini. Lviv: Pidstryhach Institute for Applied Problems of Mechanics and Mathematics, National Academy of Sciences of Ukraine. P. 5-6 (in Ukrainian)

Petruk, O. (ed.) (2014b). Ukrainske nebo. Studii nad istoriieiu astronomii v Ukraini. Lviv: Pidstryhach Institute for Applied Problems of Mechanics and Mathematics, National Academy of Sciences of Ukraine. 767 p. (in Ukrainian)

Prokopovych, F. (1979). Pro rytorychne mystetstvo. In: Prokopovych, F. Filosofski tvory v 3-kh tt. Kyiv: Naukova dumka. T. 1. P. 104-434. (in Ukrainian)

Prokopovych, F. (1980). Naturfilosofiia abo fizyka. In: Prokopovych, F. Filosofski tvory v 3-kh tt. Kyiv: Naukova dumka. T. 2. P.113-502. (in Ukrainian)

Rodichenkov, Yu.F. (2013). Prakticheskaia dukhovnost i dukhovnaia praktika alkhimii. Gosudarstvo, religiia, tserkov $v$ Rossii i za rubezhom, 4 (31): 66-86. (in Russian)

Rodichenkov, Yu.F. (2019). Dvadtsat vekov alkhimii: ot psevdoDemokrita do nashikh dnei. Saint-Petersburg: Izdatelstvo RKhGA. 565 p. (in Russian)

Rodygin, K., Rodygin, M. (2012). Alkhimiia ta naturfilosofske znannia $v$ mentalnomu ta heopolitychnomu prostori Skhidnoi Yevropy XV - XVII stolit. Skhid, 2 (116): 164-172. (in Ukrainian)

Rodygin, K.M. (2013). Na mezhi bezmezhnoho: horyzonty tsilepokladannia $v$ alkhimichnii filosofii. Hileia: naukovyi visnyk. Zbirnyk naukovykh prats. Kyiv: VIR UAN. 71 (4): 544-549. (in Ukrainian)

Rohovych, M.D. (1981). Biblioteka Feofana Prokopovycha (vytiah z opysu). In: Prokopovych, F. Filosofski tvory $v$ 3-kh tt. Kyiv: Naukova dumka. T. 3. P. 375-443. (in Ukrainian)

Ruska, J. (1937). Methods of Research in the History of Chemistry. Ambix, I, 1: 21-29. 
Semrad, O.O., Lendiel, V.H., Kokhan, O.P. (2003). Istoriia khimii. Uzhhorod: VAT «Patent». 207 p. (in Ukrainian)

Shevchenko-Savchynska, L., Balashov, K. (2014). Astronomiia v latynomovnykh tekstakh Ukrainy. In.: Petruk, O. (ed.) Ukrainske nebo. Studii nad istoriieiu astronomii v Ukraini. Lviv: Pidstryhach Institute for Applied Problems of Mechanics and Mathematics, National Academy of Sciences of Ukraine. P. 422-435. (in Ukrainian)

Soloviev, Yu.I. (red.) (1983). Vozniknovenie i razvitie khimii s drevneishikh vremen do XVII veka. Moscow: Nauka. 399 p. (in Russian)

Starostin, B.A. (1981). Drevnerusskaia nauka v kontekste srednevekovoi kultury. Voprosy istorii estestvoznaniia i tekhniki, 1: 13-23. (in Russian)

Steinfeld, J. (1959). The Theory and Practice of Alchemy. Tech. Engineering News. 40, No. 5. P. 22-25, 27-29. 32.

Stryjkowski, M. (2006). Iz knyhy «Khronika polska, Iytovska, zhmudska ta vsiiei Rusi. Krolevets, 1582». In.: Slovo mnohotsinne. Kyiv: Akonit. Book 1. P. 147-216. (in Ukrainian)
Sydor, O. (2014). Svit astronomii v obrazakh ukrainskoho mystetstva. In: Petruk, O. (ed.) Ukrainske nebo. Studii nad istoriieiu astronomii v Ukraini. Lviv: Pidstryhach Institute for Applied Problems of Mechanics and Mathematics, National Academy of Sciences of Ukraine. P. 226-317. (in Ukrainian)

Symon Pekalid (2006). Pro Ostrozku viinu pid Piatkoiu proty nyzovykh. In: Slovo mnohotsinne. Kyiv: Akonit. Book 1. P. 291-338. (in Ukrainian)

Thoren, V.E., Christianson, J.R. (2006). The Lord of Uraniborg: a biography of Tycho Brahe. Cambridge: Cambridge Univ. Press. $536 \mathrm{p}$.

Toor, K. (2011). Coleridge's Chrysopoetics: Alchemy, Authorship and Imagination. Newcastle: Cambridge Scholars Publishing. $258 \mathrm{p}$.

Verkhovskii, P.V. (1916). Uchrezhdenie dukhovnoi kollegii i dukhovnyi reglament. Materialy. T. II. Otdel piatyi. Rostov-onDon. P. 9-36 (in Russian)

Yates, F. (1972). The Rosicrucian Enlightenment. London: Routledge. $260 \mathrm{p}$.

Костянтин Родигін,

Донеиький національний університет імені Василя Стуса (м. Вінниия, Украӥна)

e-mail: rodygin88@gmail.com, ORCID 0000-0002-2948-5393

Михайло Родигін,

Інститут фізико-органічної хімії та вуглехімії ім. Л.М. Литвиненка НАН Украӥни (м. Київ, Украӥна)

e-mail: rodygin@ukr.net,ORCID0000-0001-6826-7623

\section{ТРАДИЦІЯ АЛХІМІКО-АСТРОЛОГІЧНОЇ ВЧЕНОСТІ У БІБЛІОТЕЦІ ТЕОФАНА ПРОКОПОВИЧА ТА НАВКОЛО НЕЇ}

Важлива роль алхіміко-астрологічної традиції у становленні та трансформації науки як соціального інституту в ранньомодерний час, є докладно висвітленою у західній історіографії науки. Український аспект цього загальноєвропейського явища потребує поглибленого дослідження. Стаття присвячена вивченню алхіміко-астрологічної складової української вченості доби високого бароко на прикладі науково-педагогічної діяльності Теофана Прокоповича (1677 - 1736 рр.).

Аналіз каталогу бібліотеки Прокоповича підтверджує факт приналежності алхіміко-астрологічного та магіко-фрізичного знання, що складали комплекс так званих "чорнокнижних наук», до сфери інтересів ученого. Певно, діяльність вченого окрім космогонічних міркувань та математичних розрахунків мала й практичну складову. Книги з фондів бібліотеки включають твори пізньої алхімії, що дозволяло Прокоповичу бути обізнаним щодо новітніх ідей, тенденцій та досягнень в цій та суміжних галузях знання. Це знайшло відбиток у формуванні світогляду та творчому доробку вченого.

Порівняння фактів біографій, сутності та спрямованості творчості й взаємовідносин авторів, згаданих у трактаті «Натурфілософрія, або фізика», свідчить про існування протягом XVI-XVIII ст. єдиного загальноєвропейського науково-інформаційного простору, в межах якого формувалася та трансформувалася пізньоалхімічна традиція. До цієї традиції належав і Теофан Прокопович, творчість якого виразно віддзеркалює стан та сутність української алхімічної вченості доби високого бароко. Власні міркування Прокоповича з проблем алхімії та астрології становлять предмет подальшого окремого дослідження.

Ключові слова: Теофан Прокопович, алхімія, натурфрілософрія, історія природознавства, традиція, бібліотека, українське бароко.

() Kostiantyn Rodyhin, Mykhailo Rodyhin

Надійшла до редакції: 15.11.2021

Прийнята до друку: 06.12.2021 